\title{
Pendent Venue: A Doctrine in Search of a Theory
}

\author{
Richard Corn $\dagger$
}

Imagine a case where a plaintiff brings suit against a company, based in Washington, D.C., in the Federal District Court for the District of Columbia. The plaintiff claims that the company is discriminating against him in violation of both Title VII of the Civil Rights Act of $1964^{2}$ and 42 USC $\S 1981$. $^{3}$ Since the company is based in the District of Columbia and is the only defendant, the Section 1981 claim, which is governed by the general venue statute, is properly venued. ${ }^{4}$ However, the Title VII claim is governed by its own exclusive venue provisions, and one can easily assume facts such that venue is not proper for this claim. ${ }^{6}$ The exact same facts form the basis for both claims, yet venue is proper for only the one claim and not the other. Under the hornbook rule that venue must be proper for each claim, the Title VII claim must be dismissed or the entire case must be transferred to another district, where venue would be proper for both

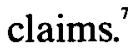

Alternatively, consider a case where a plaintiff brings two claims against a defendant in federal court, alleging violations of both the

$\dagger \quad$ B.S. 1999, Ohio State University; J.D. Candidate 2002, The University of Chicago.

1 This hypothetical is based on the facts of the case Stebbins $v$ Nationwide Mutual Insurance Co, 757 F2d 364, 364-66 (DC Cir 1985).

242 USC $\$ \$ 2000$ e et seq (1994).

342 USC $\$ 1981$ (1994) (creating a cause of action for various civil rights violations).

4 See 28 USC $\$ 1391$ (b) (1994) ("A civil action ... may ... be brought ... in (1) a judicial district where any defendant resides, if all defendants reside in the same State.").

5 See 42 USC $\$ 2000 \mathrm{e}-5(\mathrm{f})(3)$ :

[A Title VII] action may be brought in any judicial district in the State in which the unlawful employment practice is alleged to have been committed, in the judicial district in which the employment records relevant to such practice are maintained and administered, or in the judicial district in which the aggrieved person would have worked but for the alleged unlawful employment practice.

See also Johnson v Payless Drug Stores Northwest, Inc, 950 F2d 586, 587-88 (9th Cir 1991) (holding that the general venue provision of 28 USC $\$ 1391$ does not apply to Title VII actions).

6 For instance, one could assume that the plaintiff sought employment in some district outside of the District of Columbia, and the relevant records were held in this other district. Then, none of the three categories under 42 USC $\$ 2000 \mathrm{e}-5(f)(3)$ would apply.

7 See Beattie v United States, 756 F2d 91, 100 (DC Cir 1984) (noting that the "general rule is that venue must be established as to each separate cause of action"). See also Charles Alan Wright, Arthur R. Miller, and Edward H. Cooper, 15 Federal Practice and Procedure $\$ 3808$ at 80 (West 2d ed 1986) ("[I]n a case in which multiple claims are joined, the venue must be proper for each claim."). 
Racketeer Influenced and Corrupt Organizations ("RICO") $\mathrm{Act}^{8}$ and state law." The same core of facts serves as the basis for both claims. The RICO claim is properly venued due to the broad, supplementary venue provisions of the RICO Act, ${ }^{10}$ but the state law claim is not properly venued under the general venue statute. Again, under the hornbook rule that venue must be proper for each claim," the state law claim must be dismissed or transferred.

Dissatisfaction with this outcome has led many courts to apply a doctrine called "pendent venue." According to this doctrine, a claim that is not properly venued standing alone can still be heard by the court as long as another properly venued claim "arising out of a common nucleus of operative facts" ${ }^{12}$ is also brought at the same time in the same district. This doctrine developed due to the analogy with pendent jurisdiction, whereby a state claim that could not otherwise be heard in federal court would be allowed if attached to a factually similar federal claim. ${ }^{13}$ Pendent venue is defended on the grounds that "if procedural convenience is enough to avoid the constitutional limitations on the jurisdiction of the federal court, it should suffice also to dispense with the purely statutory requirements as to venue." ${ }^{, 4}$ As with pendent jurisdiction, the use of pendent venue is discretionary on the part of the court, with the usual touchstones of "judicial economy, convenience, and fairness to the litigants" ${ }^{\text {, }}$ determining when its use is appropriate. The doctrine, however, is not thoroughly thought out and

$8 \quad 18$ USC $\$ 1961$ et seq (1994).

9 A good example of such a case is Firemen's Annuity \& Benefit Fund of Chicago $v$ Union Planters National Bank, 1987 US Dist LEXIS 4510 (N D III), where pendent state common law claims were brought along with a RICO claim (as well as a claim under federal securities law). Id at $* 1$.

10 See 18 USC $\$ 1965$. Amongst other districts, a civil action under RICO can be brought against a defendant in "any district in which such person resides, is found, has an agent, or transacts his affairs." Id $\$ 1965$ (a). Note that the venue provisions in RICO supplement the general venue provisions, and thus a RICO claim can be brought using either the general or the special venue provisions. See Miller Brewing Co v Landau, 616 F Supp 1285, 1291 (E D Wis 1985) (stating that "[t]he venue provisions of $\S 1965$ are not exclusive; rather, they are supplemental to those found in 28 U.S.C. $\$ 1391$ "). Thus, necessarily, a RICO claim will have an equal or greater range of districts in which venue is proper over any claim that falls under the general venue provision, such as state claims.

11 See note 7.

12 Beattie, 756 F2d at 101.

13 The classic Supreme Court case on pendent jurisdiction is United Mine Workers $v$ Gibbs, 383 US 715 (1966), where a state claim arising from the same facts as a federal labor claim was heard in federal court, despite the lack of independent grounds on which a federal court could hear the state claim.

14 Beattie, 756 F2d at 101, quoting Charles Alan Wright, The Law of Federal Courts $\S 10$ at 32 (West 4th ed 1983).

15 Seamon v Upham, 563 F Supp 396, 399 (E D Tex 1983). 
defined, and there are some disagreements as to its extent and appropriateness.

The sources of confusion in the pendent venue doctrine are two seemingly conflicting principles that courts follow in the venue context. The first is the pursuit of judicial economy and convenience, which are the very foundations of the venue provisions. If two claims arise entirely out of the same facts, why waste judicial resources hearing the two separately, or why force the plaintiff to litigate both claims in a different district when the more significant claim is properly venued? Against this principle, however, is the rule that Congress has the final word when it comes to venue, and the federal courts must follow the statutes as written by Congress. If the venue provisions in question do not allow a particular claim to be heard in a particular district, how can a federal court ignore this seemingly clear mandate from Congress? Many courts seem to overlook this conflict, treating one principle as controlling and failing to consider the other. The solution, however, is that these two principles can be reconciled in a way that does violence to neither. By allowing for a broad notion of the phrases "claim" and "cause of action," by noting the default nature of the general venue provision, and by adhering to the intent of Congress as evidenced by the words of the statute, a theory can be devised whereby judicial economy and congressional intent may coexist.

This Comment explores the doctrine of pendent venue. Part I describes the current approaches to the pendent venue doctrine. Part II critiques various approaches to pendent venue, as adopted by many courts in the United States. Part III then proposes a coherent theory of pendent venue, one that explains and justifies the well accepted uses of pendent venue and also stays as close as possible to the language and intent of the venue provisions.

\section{Pendent Venue in The Courts}

This Part discusses the approaches to pendent venue taken by the courts. The cases that come before the courts almost always fall into

16 Compare Serpico v Laborers' International Union of North America, 1995 US Dist LEXIS 11237, *13-15 (N D Ill) (extending pendent venue to a situation where no other court had yet used it), with Boggs v United States, 987 F Supp 11, 19 (D DC 1997) (rejecting pendent venue in the case before it and declaring that "this court will not rely upon the unique facts from Beattie to create a general doctrine of pendent venue").

17 This Comment focuses only on claims brought by plaintiffs and will not discuss "ancillary" venue, whereby third party claims, counterclaims, and interpleader and impleader claims can be brought even when the action, if brought alone, would not be properly venued. The justification for the use of "ancillary" venue is a focus on the language "where an action may be brought" and concludes that counterclaims and the like are not being "brought" anew, but instead merely being appended to an already-brought action. See Seamon, 563 F Supp at 398-99 n 2 . 
two basic categories. In the first category, a plaintiff brings two interrelated claims, one of which arises under a federal statute governed by a specialized venue provision that narrows the scope of the general venue provision ${ }^{18}$ and the other governed by the general venue provision. The case is brought in a district allowed under the general venue provision, but which falls outside the specialized venue provision. Here, the plaintiff argues for the use of pendent venue in effect to override the specialized venue provision. These claims will be referred to as "narrow special venue claims." In the second category, again two claims are brought, one of which is brought under a federal statute governed by a specialized venue provision that broadens or supplements the scope of the general venue provision, ${ }^{19}$ the other governed by the general venue provision. ${ }^{20}$ Here, the plaintiff brings the case in a district allowed by the specialized venue provision but not allowed by the general venue provision. The plaintiff in effect argues for an overriding of the general venue provision. These claims will be referred to as "broad special venue claims." After a brief background discussion on venue, this Part examines the different approaches courts have used in these two basic categories.

\section{A. An Introduction to Venue}

The actual meaning of "venue" is somewhat vague. Basically, it is the location of the court where one can bring a particular claim. ${ }^{21}$ There is a common law tradition to venue, ${ }^{22}$ although modern courts now consider venue to lie wherever an act of Congress might specify. ${ }^{23}$

18 Other federal statutes contain narrow specialized venue provisions, but the bulk of the reported cases fall under patent law, Title VII, or the Federal Tort Claims Act. One example of a case falling outside these three categories is one arising under the Labor-Management Reporting and Disclosure Act ("LMRDA"), 29 USC $\S 402$ et seq (1994), which is governed by a narrow special venue provision. See id $\$ 412$. Occasionally, claims arising under other sections of the labor laws arise out of the same nucleus of operative facts as an LMRDA claim. These other claims are often governed by a less strict venue provision. Thus, as can be predicted, pendent venue is often asserted in an attempt to bring all the claims in one district. In at least one notable case, Serpico v Laborers' International Union of North America, 1995 US Dist LEXIS 11237 (N D Ill), the District Court for the Northern District of Illinois allowed pendent venue, id at *15. The court noted that generally courts do not allow the application of pendent venue to defeat specific venue provisions. Id at *13-14. The court then rejected this approach, explaining that "the general venue provision ... seems to express congressional intent no less than special venue provisions in particular statutes. If pendant venue serves to cure inefficiency and unfairness created by the general statutory rule, [there is] no reason why it should not cure the same ills in cases governed by statutory exceptions." Id at *14-15. Thus, the court allowed the claims.

19 Examples of these include RICO and federal securities law claims.

20 The claims governed by the general venue provision shall be referred to in this Comment as "general venue claims."

21 See Wright, Law of Federal Courts $\S 10$ at 238 (cited in note 14) (describing venue as the concept that "there is a particular court or courts in which an action should be brought").

22 See id ("[V]enue ... is of ancient common law lineage.").

23 Wright, Miller, and Cooper, 15 Federal Practice and Procedure $\$ 3803$ at 10 (cited in 
It is strictly a statutory notion; constitutional principles are not implicated. ${ }^{24}$ Thus, it is perhaps best to think of venue as simply the districts in which Congress allows certain claims to be brought. It is also good to keep in mind exactly what venue is not: it is not a personal or Article III jurisdictional question, but instead is independent of these other two requirements. ${ }^{25}$ Personal jurisdiction can exist without venue being proper in a particular district and vice versa. ${ }^{26}$

There are two main types of venue provisions used by Congress. One type is a provision attached to a statute, intending to control all claims brought under the statute. The other type is the general venue provision. This applies to all claims brought in federal court where the claim is not governed by a statute bearing its own venue provision." State claims brought into federal court through diversity jurisdiction, for instance, will clearly be covered by the general venue provision. The existence of a special venue provision in a statute does not rule out the use of the general venue provision; some statutes have a special venue provision intended to supplement, and hence expand, the general venue provision. ${ }^{28}$

The main purpose of the venue provisions is apparently convenience for the defendant, plaintiff, witnesses, and court system. ${ }^{29}$ The dis-

note 7).

24 See Wright, Law of Federal Courts $\S 10$ at 239 (cited in note 14) ("It is wholly settled by a long and unbroken line of authority that venue is controlled entirely by Acts of Congress.").

25 See Neirbo Co v Bethlehem Shipbuilding Corp, Ltd, 308 US 165, 167-68 (1939).

26 See, for example, Celsion Corp v Stearns Management Corp, 2001 US Dist LEXIS 413 (D Md) (noting that the district court had personal jurisdiction but not venue). For corporations, however, 28 USC $\$ 1391$ (c) does create an overlap between personal jurisdiction and venue, by defining "resides" for corporate defendants in terms of personal jurisdiction.

27 The pertinent parts of the general venue provision are:

(a) A civil action wherein jurisdiction is founded only on diversity of citizenship may, except as otherwise provided by law, be brought only in (1) a judicial district where any defendant resides, if all defendants reside in the same State, (2) a judicial district in which a substantial part of the events or omissions giving rise to the claim occurred, or a substantial part of property that is the subject of the action is situated, or (3) a judicial district in which the defendants are subject to personal jurisdiction at the time the action is commenced, if there is no district in which the action may otherwise be brought.

(b) A civil action wherein jurisdiction is not founded solely on diversity of citizenship may, except as otherwise provided by law, be brought only in (1) a judicial district where any defendant resides, if all defendants reside in the same State, (2) a judicial district in which a substantial part of the events or omissions giving rise to the claim occurred, or a substantial part of property that is the subject of the action is situated, or (3) a judicial district in which any defendant may be found, if there is no district in which the action may otherwise be brought.

28 USC \$ 1391(a)-(b).

28 RICO Act claims and federal securities claims are two examples. See Miller Brewing Co $v$ Landau, 616 F Supp 1285, 1291 (E D Wis 1985) (noting that the RICO venue provisions supplement rather than replace the general venue provision); Miller $v$ Asensio, $101 \mathrm{~F}$ Supp 2d 395, 407-08 (D SC 2000) (using general venue provision to find proper venue for securities suit).

29 See Leroy v Great Western United Corp, 443 US 173, 183-85 (1979) (noting that, gener- 
tricts in which one can bring suit are limited to prevent a plaintiff from bringing a suit in a district highly inconvenient for the defendant or in a district entirely unrelated to the claim. ${ }^{30}$ In particular, one court has described the "considerations unique to the context of venue" as "primarily a matter of convenience of litigants and witnesses." one should not rely too much on these broad principles and purposes to help interpret venue statutes; the United States Supreme Court in Leroy $v$ Great Western United Corp ${ }^{32}$ stated quite clearly that venue "is not one of those vague principles which, in the interest of some overriding policy, is to be given a 'liberal' construction." ${ }^{33}$ In this case, a strong argument can and was made that convenience and economy mandated a particular interpretation of the venue provisions. ${ }^{34}$ The Supreme Court, recognizing these arguments, rejected the plaintiffs' position on the grounds of adherence to the plain meaning of the statute. ${ }^{35}$ More recently, in Lexecon Inc v Milberg Weiss Bershad Hynes \& Lerach, the Supreme Court employed a strict textual analysis on the text of a venue provision to come to its conclusion. ${ }^{37}$ The arguments by the plaintiff concerning policy and convenience were dismissed offhand. Thus, the fundamental and best reason behind venue provisions, for the purpose of judicial interpretation at least, is perhaps simply that Congress said so.

\section{B. Narrow Special Venue Claims Pendent to General Venue Claims}

Narrow special venue claims are claims brought under statutes governed exclusively by their own special venue provisions, not the general venue provision. As one can imagine, plaintiffs will sometimes wish to bring such a claim in a different district from those allowed.

ally, the purpose of statutorily specified venue is to protect the defendant from unfairness and inconvenience). See also Beattie $v$ United States, 756 F2d 91, 103 (DC Cir 1984) (stating that "[venue] is also oriented to the convenience of the court system").

30 See Leroy, 443 US at 184-85.

31 Beattie, 756 F2d at 103, quoting Denver \& Rio Grande Western Railroad Co v Brotherhood of Railroad Trainmen, 387 US 556, 560 (1967).

32443 US 173 (1979).

33 Id at 184 n 18, quoting Olberding v Illinois Central Railroad Co, Inc, 346 US 338, 340 (1953).

34 Leroy, 443 US at 188-89 (White dissenting) (noting that the majority's interpretation of the venue provision would possibly force plaintiffs to bring suits in up to thirty-six different states).

35 Id at $184-86$.

36523 US 26 (1998).

37 There is some discussion of legislative history, but this history only confirms the more extensive textual analysis undertaken by the Court. Id at $39-40$.

38 Id at 40 . Only a single sentence refers to policy arguments that were perhaps made: "[Appellee] may or may not be correct that permitting transferee courts to make selfassignments would be more desirable than preserving a plaintiff's choice of venue ... but the proper venue for resolving that issue remains the floor of Congress." Id. 
One technique used is to bring a pendent general venue claim along with the narrow special venue provision, in a district allowed by the general venue provision. The following discussion addresses the judicial response to this tactic in the patent infringement, Title VII, and Federal Tort Claims Act contexts.

\section{Patent infringement claims.}

A patent infringement claim is covered by a specialized venue provision. ${ }^{39}$ An action for patent infringement may be brought in a district "where the defendant resides, or where the defendant has committed acts of infringement and has a regular and established place of business." ${ }^{40}$ This venue provision does not supplement the general venue statute, and thus it would seem a patent infringement claim standing alone may not be brought under the general venue statute. ${ }^{41}$

A common approach taken by plaintiffs when presented with this restrictive venue provision is to bring a related claim under a more generous venue provision, and then try to attach the patent infringement claim through pendent venue. ${ }^{42}$ Some early patent infringement cases permit this application of pendent venue. In Dolly Toy Co $v$ Bancroft-Rellim Corp, ${ }^{43}$ the court noted that venue was proper for all claims, but "even if jurisdiction was doubtful," since "[a]pproximately the same proofs will be made to substantiate each of the two causes of action," the proper venue of the copyright claim would allow the patent infringement claim to be heard. ${ }^{44}$ In Ferguson v Ford Motor Co,

3928 USC $\$ 1400$ (b) (1994).

40 Id.

41 See Fourco Glass Co v Transmirra Products Corp, 353 US 222, 229 (1957) (holding that 28 USC $\$ 1400(\mathrm{~b})$ is "the sole and exclusive provision controlling venue in patent infringement actions"). There are some exceptions, namely that the venue provision applicable to alien defendants, 28 USC $\$ 1391$ (d), can be used against an alien defendant even in a patent infringement case. See Brunette Machine Works, Ltd v Kockum Industries, Inc, 406 US 706, 714 (1972). Also, for corporate defendants, 28 USC $\$ 1391$ (c), defines the phrase "resides" to include any judicial district in which personal jurisdiction exists over the corporation. This expanded definition applies as well to patent infringement claims. See VE Holding Corp v Johnson Gas Appliance Co, 917 F2d 1574, 1582-84 (Fed Cir 1990). This, of course, significantly broadens the number of districts for which venue is appropriate in patent infringement cases against corporations. Still, the patent infringement statute remains unchanged for noncorporate American citizens. See id at 1580 n 17.

42 See PKWare, Inc v Meade, 79 F Supp 2d 1007, 1018 (E D Wis 2000) (involving a plaintiff bringing state law and federal copyright claims with pendent patent infringement claims); Network Systems Corp v Masstor Systems Corp, 612 F Supp 438, 438 (D Minn 1984) (involving a plaintiff bringing, inter alia, breach of contract and misappropriation of trade secret claims); Bradford Novelty Co v Manheim, 156 F Supp 489, 490 (S D NY 1957) (involving a plaintiff bringing state common law claim of unfair competition and a patent infringement claim).

4397 F Supp 531 (S D NY 1951).

44 Id at 536.

4577 F Supp 425 (S D NY 1948). 
the identical approach was suggested. ${ }^{46}$ These cases found that venue was satisfied for all of the claims, and thus the comments pertaining to pendent venue were mere dicta.

The vast majority of courts dealing with situations where venue was not satisfied for the patent infringement claim have come to a different result: Pendent venue cannot be used to override the venue provision of the patent laws." "[The patent] special venue statute reflects a Congressional awareness of the technical nature of patent litigation and the particular advantage in limiting its prosecution to forums where the acts of infringement occurred and where the defendant is located." ${ }^{48}$ This reasoning, that the special venue provision represents a strong congressional intent to limit the districts where patent infringement claims can be brought and that allowing a plaintiff to bring in the patent claim as pendent to another claim with a broader venue provision would defeat this intent, is found in the many cases that discuss pendent venue in the patent infringement context. ${ }^{49}$ This approach appears in other circumstances as well, and will be referred to as the "special venue" approach.

The case of Goggi Corp v Outboard Marine Corp ${ }^{50}$ is instructive. Here, a plaintiff brought several antitrust claims against defendants, and a patent infringement claim against one particular defendant. The patent infringement was allegedly part of the defendant's attempt to monopolize a particular market. ${ }^{52}$ The venue of the antitrust claim

46 See id at 436.

47 See PKWare, 79 F Supp 2d at 1018-19; Johlar Industries, Inc v Essex Engineering Co, 1988 US Dist LEXIS 7623,*8 (N D Ill); Zin-Plas Corp v Plumbing Quality Agf Co Ltd, 622 F Supp 415, 422 (W D Mich 1985); Network Systems, 612 F Supp at 440; Max Daetwyler Corp v Input Graphics, Inc, 541 F Supp 115, 117-18 (E D Pa 1982); Hoffacker v Bike House, 540 F Supp 148, 149-50 (N D Cal 1981); Goggi Corp v Outboard Marine Corp, 422 F Supp 361, 366 (S D NY 1976); Locke Manufacturing Co v Sabel, 244 F Supp 829, 830-31 (W D Ky 1965); Bradford Novelty, $156 \mathrm{~F}$ Supp at 491. But see Hsin Ten Enterprises USA, Inc v Clark Enterprises, 2000 US Dist LEXIS 18717, *34-36 (S D NY) (ruling that pendent venue could be applied to patent infringement claims).

48 Hoffacker, 540 F Supp at 149.

49 See, for example, Johlar, 1988 US Dist LEXIS 7623 at *8 ("The patent venue statute... represents a congressional awareness of the technical nature of patent litigation and the particular advantages in limiting patent proceedings .... [The plaintiff] cannot rely on a theory of pendent venue and use other claims to ferryboat in [the patent infringement claim]."); Zin-Plas, 622 F Supp at 422 ("[A] party cannot circumvent the intent behind the statute merely by joining a related federal claim to a claim of patent infringement."); Network Systems, 612 F Supp at 440 (citing and reiterating the congressional intent argument made in Hoffacker); Bradford Novelty, 156 F Supp at 491 ("The patent venue statute reflects a legislative policy recognizing the technical and intricate nature of patent litigation. Because of the obvious difficulty involved in a court attempting to ascertain from the mass of technical data presented the pertinent and determinative facts, Congress saw fit to narrowly confine the venue provisions applicable to this type action.").

$50 \quad 422$ F Supp 361 (S D NY 1976).

51 Id at 363,365 .

52 Id at 365. 
was proper, unlike the venue of the patent infringement claim. ${ }^{53}$ The district court rejected the use of pendent venue, noting that the patent venue provision provided the exclusive locations where such a claim could be brought. This case is noteworthy, since the patent infringement claim can be argued to be a subset of the "principal" antitrust claim against the defendant, and yet the district court still refused to use the doctrine of pendent venue.

A very recent case, $H$ sin Ten Enterprises USA, Inc $v$ Clark Enterprises, ${ }^{56}$ rejected the approach of these cases. In this case, the plaintiff had an exclusive right to manufacture machinery under a patent and produced the machinery under a particular trademark." The defendant, residing in Kansas, allegedly produced the machines as well, under the same trademark.

The plaintiff sued in New York. ${ }^{59}$ The trademark was violated by the defendant's use of it on an interactive website in New York, and thus under 28 USC $\S 1391$ (b), venue was appropriate there. ${ }^{60}$ Since the defendant did business as a sole proprietorship with no established business in New York, and also did not reside in New York, the patent claim was not properly venued in New York. ${ }^{61}$

The court noted that most, if not all, other courts reject the use of pendent venue for patent infringement claims. ${ }^{62}$ Then, however, the court observed that all but one of these cases arose before the 1988 modification to 28 USC $\S 1391$ (c), which broadened the definition of "resides" for venue purposes for corporate defendants. ${ }^{63}$ With this broadened definition, the court claimed that the "restrictive" view of the patent venue provision was no longer appropriate. ${ }^{64}$ In light of the

53 Id (noting "plaintiffs apparently concede that their patent infringement claim does not meet the standard of 28 U.S.C. $\S 1400$ (b) in this district").

54 Id. However, the district court also noted that there would be variances in the proofs and facts surrounding the two claims and thus held that judicial economy would not be served by trying the two claims together. See id at 366.

55 Thus, this result is quite possibly different from the one that would occur using the "principal cause of action" approach to pendent venue. See text accompanying notes 71-82. Of course, the district court also noted that factual differences between the claims existed, and thus one could argue that pendent venue is inappropriate for this reason. Yet, the facts of this case could be easily modified so that there would be a similarity of proofs between the claims. Thus, a "principal cause of action" approach to pendent venue could conceivably result in a patent infringement claim being heard outside the judicial districts allowed under 28 USC $\$ 1400$ (b). The significance of this fact will be discussed later in this Comment. See Part III.D.

562000 US Dist LEXIS 18717 (S D NY).

$57 \quad$ Id at $* 3$.

58 Id at *4.

59 Id at *5.

60 Id at *24-30.

61 Id at *30-31.

62 See id at *37.

63 See id at *39-40.

64 See id. 
$H$ sin decision, the status of the pendent venue doctrine in the patent infringement context is now less certain.

\section{Title VII litigation.}

Title VII claims are perhaps among the most common claims in which pendent venue is invoked, possibly because Title VII has a restrictive venue provision, ${ }^{65}$ and many other federal statutes exist that cover similar acts. ${ }^{66}$ Examples of federal claims in which plaintiffs attempt to bring in a pendent Title VII claim include Section 1981 claims," Age Discrimination in Employment Act ("ADEA") claims," Equal Pay Act claims, and claims based on violations of Executive Orders. ${ }^{70}$ Courts have reached inconsistent conclusions on the many cases concerning Title VII and pendent venue. In fact, the two major approaches to pendent venue arise from Title VII cases.

The first approach is commonly called the "principal cause of action" approach to pendent venue. It first makes its appearance in the case of Laffey $v$ Northwest Airlines, Inc. ${ }^{71}$ Here, the plaintiff brought suit under both the Equal Pay Act and Title VII, alleging that female flight attendants were paid less for equivalent work. ${ }^{72}$ The district court declared that "what is essentially at issue [ ] is equal pay for equal work" and without further discussion held that the Equal Pay Act claim was the "principal cause of action.", Since venue for the Equal Pay Act is governed by the general venue statute, and since

6542 USC \& 2000e-5(f)(3).

66 Examples include, 42 USC $\$ 1981$ (1994) (protecting a citizen's equal rights from impairment); the Age Discrimination in Employment Act, 29 USC $\$$ 621 et seq (1994) (protecting against employment discrimination due to age); the Rehabilitation Act, 29 USC $\S 791$ et seq (1994) (protecting individuals with disabilities from employment discrimination); and the Equal Pay Act, 29 USC $\$ 206$ (d) (1994) (barring sex-based pay differentials).

67 See Stebbins v Nationwide Mutual Insurance Co, 757 F2d 364, 365 (DC Cir 1985).

68 See Kravitz $v$ Institute for International Research, Inc, 1993 US Dist LEXIS 15669, *1 (E D Pa).

69 See Laffey v Northwest Airlines, Inc, 321 F Supp 1041, 1042 (D DC 1971).

70 See United States $v$ Trucking Management, Inc, 1979 US Dist LEXIS 10951, *28-29 (D DC).

$71321 \mathrm{~F}$ Supp 1041 (D DC 1971). This is not the first case in which this idea is mentioned. See Bradford Novelty Co v Manheim, 156 F Supp 489, 491-92 (S D NY 1957) (stating that "[w]here the court is properly vested with one cause of action embodying the principal or fundamental controversy between the parties the court may justifiably retain jurisdiction over ancillary or related issues"). But the Laffey case is the first case in which the "principal cause of action" approach was clearly used to override a special venue provision. In Bradford Novelty, the court rejected the use of pendent venue, based on the fact that the principal cause of action was the one that was covered by the special venue provision. See id at 491 .

72 Laffey, 321 F Supp at 1042.

73 Id.

74 Id. 
venue was proper under this statute, the Title VII claim could be brought using pendent venue, the court held."

The District Court for the District of Columbia reaffirmed this approach in Hayes $v$ RCA Service $\mathrm{Co}^{76}$ although the two claims in that decision were a Title VII claim and a Section 1981 claim. ${ }^{n}$ Here, the court reasoned that since "Title VII is a statute which has been specifically fashioned by Congress to remedy employment discrimination," ing... involve employment discrimination,", the principal cause of action was the Title VII claim. ${ }^{80}$ Thus, since venue for the Title VII claim was improper, it could not be heard in this district. ${ }^{81}$ Some other courts have also used the "principal cause of action" approach, although almost always the Title VII claim is found to be the principal claim.

For other courts, the analysis of Title VII claims more closely mirrors the "specialized venue" approach found in patent infringement claims, where venue must be proper for the cause of action that is

75 Id.

76546 F Supp 661 (D DC 1982).

77 Id at $662-63$.

78 Id at 664.

79 Id.

80 Id at 664-65. In fact, the court goes so far as to suggest that whenever a Title VII and a Section 1981 claim are joined, the Title VII claim should be considered the principal claim. See id at 665 . The reasoning given by the court is quite similar to the reasoning found in the patent infringement cases for why pendent venue is improper: namely, that

Congress, in writing a narrower, specific venue provision for Title VII, obviously intended that Title VII actions be confined to certain districts. Nevertheless, unless Title VII is considered the primary cause of action for this type of employment discrimination case, the venue provision intended by Congress could be effectively written out of the statute by using a companion cause of action under 42 U.S.C. $\$ 1981$ as a basis for venue and then invoking the doctrine of pendent venue... Therefore, in order to preserve the intent of Congress as to permissible venue in Title VII actions, the Court feels compelled to apply a rule in an employment discrimination case such as this, that Title VII will be considered the principal cause of action and a companion cause of action under 42 U.S.C. $\$ 1981$ will be only secondary.

Id at 665 (citations omitted). This approach has been rejected explicitly only once, in a concurring opinion, Stebbins, 757 F2d at 369 n 7 (Edwards concurring). However, Judge Edwards is not clear as to how one should determine what the "principal" claim is, if the fairly workable approach of Hayes is rejected.

81 Hayes, 546 F Supp at 664.

82 See Lengacher v Reno, 75 F Supp 2d 515, 519-20 (E D Va 1999) (involving a Rehabilitation Act claim, which uses the same venue provision as Title VII, and an ADEA claim; analyzing pendent venue under both the "principal claim" approach and the "specialized venue" approach); Bumgarner v Japan Airlines Co, Ltd, 1992 US Dist LEXIS 15109, *9-10 (N D Cal) (noting that nonprincipal claims are based on ERISA violations and state wrongful termination claim); Washington v General Electric Corp, 686 F Supp 361, 362 (D DC 1988) (involving a plaintiff admitting that the Title VII claim is the principal claim). See also Garrel $v$ NYLCare Health Plans, Inc, 1999 US Dist LEXIS 9778, *13-15 (S D NY) (refusing to rule on which claim is principal without a full briefing on the issue). 
covered by a narrow specialized venue provision. ${ }^{83}$ In McCarthy $v$ $K F C$ Corp, ${ }^{84}$ the plaintiff attempted to bring both a general venue claim and a pendent Title VII claim. ${ }^{85}$ The district court held that "an assertion of pendent venue over the Title VII claim would effectively supercede [the] Congressionally mandated exclusivity [of the Title VII venue provision]." Similar declarations are found in many other cases, even cases found in the District Court for the District of Columbia, that reject the use of pendent venue in Title VII cases. ${ }^{87}$ This argument appears not only in Title VII cases but also in cases concerning Americans with Disabilities Act ("ADA") claims and Rehabilitation Act claims, which incorporate the Title VII venue provision.

\section{Federal Tort Claims Act ("FTCA").}

Another set of cases in which pendent venue occasionally is invoked is FTCA claims. The FTCA ${ }^{89}$ narrowly limits where suits may be brought against the United States for tort claims. Venue is proper "only in the judicial district where the plaintiff resides or wherein the act or omission complained of occurred."

Beattie v United States ${ }^{91}$ is an important case for several reasons, but, most importantly for our purposes, it accepted and established the

83 See text accompanying notes 47-55.

841984 US Dist LEXIS 14781 (N D Ill).

85 Id at *1.

86 Id at *8 $\mathrm{n} 8$. This statement is pure dicta, since the court found that venue was inappropriate for all of the plaintiff's claims. See id at *7.

87 See, for example, Schmidt v Delta Airlines, Inc, 1999 US Dist LEXIS 4400, *5 (E D La) (discussing an ADA case, which incorporates Title VII venue requirements, and stating that "Congress clearly intended to limit venue to the judicial districts concerned with the alleged discrimination"); McManus $v$ Washington Gas Light Co, 1991 US Dist LEXIS 14539, *11 (D DC) (noting that "Congress has expressly limited the federal courts that can hear Title VII cases, and thus the exercise of a judge-made exception would fly in the face of clear Congressional will"); Bartel v Federal Aviation Administration, 617 F Supp 190,198 n 33 (D DC 1985) ("In enacting the special Title VII venue statute Congress deliberately sought to limit the venues in which Title VII actions might be brought. Under such circumstances, the Court lacks the authority to ignore the congressional intent to limit venue by finding pendent venue."); Trucking Management, 1979 US Dist LEXIS 10951 at *29 (stating that "to allow pendent venue here would circumvent and defeat the intent of Congress to confine Title VII actions to certain prescribed districts") (citations omitted).

88 See Schmidt, 1999 US Dist LEXIS 4400 at *5 (ADA claim); Lengacher, 75 F Supp 2d at 519-20 (Rehabilitation Act Claim).

89 Federal Tort Claims Act, Pub L No 79-601, 60 Stat 842 (1946), codified at 28 USC $\$ \S$ 1346(b), 2671 et seq (1994).

9028 USC $\$ 1402$ (b) (1994).

91756 F2d 91 (DC Cir 1984).

92 It is known more commonly for establishing the principle, since rejected by the United States Supreme Court, that Antarctica was not a foreign country for the purposes of the FTCA. See Smith v United States, 507 US 197, 204-05 (1993) (ruling that the waiver of sovereign immunity for tort claims against the United States found in the Federal Tort Claims Act did not apply to torts committed in Antarctica). 
doctrine of pendent venue in the context of the FTCA. ${ }^{93}$ The pendent venue doctrine had previously only occasionally been mentioned and adopted by various federal district courts. Beattie's justification for pendent venue is often cited by federal courts as support for the doctrine's use."

The lawsuit in Beattie arose out of the crash of a New Zealand aircraft into Mount Erebus, located in Antarctica. ${ }^{* 6}$ The plaintiffs filed a wrongful death lawsuit in the United States District Court for the District of Columbia against the United States under the FTCA. ${ }^{97}$ The complaint alleged negligence of United States naval air traffic controllers at McMurdo Air Station in Antarctica ("Antarctica claim"), and also alleged negligence in selection, training, and supervision of naval personnel at the base by Department of Defense officials ("headquarters claim")." The headquarters claim satisfied the venue requirement. ${ }^{100}$ However, the acts or omissions for the Antarctica claim all occurred in Antarctica. ${ }^{101}$ Since there are no judicial districts in Antarctica, this claim seemingly could not be brought anywhere. ${ }^{102}$ The district court, however, refused to dismiss the case, and the Court of Appeals for the District of Columbia agreed to hear the U.S. Government's interlocutory appeal. ${ }^{103}$

The court, after noting the general rule that venue must be proper for each separate cause of action, focused on the word "separate." broad meaning of the phrase "cause of action" is appropriate. ${ }^{105}$ Where the two claims really "amount to only one cause of action with two grounds for relief," then proper venue as to one federal ground will

$93756 \mathrm{~F} 2 \mathrm{~d}$ at 100.

94 See Seamon v Upham, 563 F Supp 396, 398-99 (E D Tex 1983) (noting existence of pendent venue doctrine but declining to use it); Goggi, 422 F Supp at 366 (noting that "[t]he socalled theory of 'pendent venue' has received limited application and acceptance").

95 See Mark E. Mitchell, Inc v Charleston Library Society, 114 F Supp 2d 259, 262 (S D NY 2000) (citing Beattie extensively to justify use of pendent venue); Dooley v United Technologies Corp, 786 F Supp 65, 81 (D DC 1992) (citing Beattie).

96 See Beattie, 756 F2d at 92.

97 See id at 93.

98 See id. This section of the Comment uses the same shortened descriptions of the two claims as in the opinion.

99 See id.

100 See id.

101 See id (noting the claim alleged negligence on the part of traffic controllers at McMurdo Naval Air Station in Antarctica).

102 See id at 104 (noting that under the government's theory of venue, venue would be proper "nowhere").

103 Id at 93. To solve this apparent absurdity, the Court of Appeals adopted the doctrine of pendent venue, using "two discrete but interrelated theories." Id at 100.

104 See id.

105 Id, citing James Wm. Moore, Moore's Federal Practice Il 0.142[3] (Matthew Bender 2d ed 1984). 
support adjudication of both grounds. ${ }^{106}$ Using a broad definition of cause of action found in a previous Supreme Court decision, ${ }^{107}$ the court of appeals concluded that the plaintiffs were seeking damages essentially for a single wrong, ${ }^{108}$ and were alleging against the same defendant two separate grounds of relief. Thus, under this "one cause of action" approach, the proper venue of the headquarters claim could be used to bring in the Antarctica claim.

The court of appeals also discussed a similar, yet distinct approach to pendent venue, the "procedural efficiency" approach. Analogizing to pendent jurisdiction, the court of appeals noted that since United Mine Workers v Gibbs, ${ }^{110}$ a federal court could hear state claims that arose out of the same "common nucleus of operative facts" dicial efficiency would be served by hearing the claims together. ${ }^{112}$ Since "procedural convenience is enough to avoid the constitutional limitations on the jurisdiction of the federal court, it should suffice also to dispense with the purely statutory requirements as to venue." Applying the efficiency approach, the court of appeals approved use of the headquarters claim as a hook to bring in the Antarctica claim. ${ }^{114}$ The District of Columbia was the most convenient forum as witnesses would be "either here in Washington, D.C. or scattered around the globe," and "[r]ecords relating to the accident investigation of the Air New Zealand flight would be located in Washington, D.C." given that all parties were already properly before the district court, "it does not seem too inconvenient to include the Antarctica claims in the same lawsuit." ${ }^{116}$ Thus, under either the one cause of action or the efficiency approach, venue was proper for the Antarctica claim."

The FTCA involves an issue not present in other pendent venue cases: waiver of sovereign immunity. The United States "may choose the conditions under which a suit against it is to proceed."

106 Beattie, 756 F2d at 100.

107 Hurn v Oursler, 289 US 238, 245-47 (1933).

108 In this case, wrongful death. See Beattie, $756 \mathrm{~F} 2 \mathrm{~d}$ at $100-01$.

109 See id.

110383 US 715 (1966).

111 Beattie, 756 F2d at 101.

112 See id at 103 (noting the policy considerations used in evaluating pendent jurisdiction claims).

113 Id at 101, citing Wright, Law of Federal Courts $\S 10$ at 32 (cited in note 14).

114 See Beattie, 756 F2d at 104.

115 Id.

116 Id.

117 Some courts misunderstand Beattie as holding that pendent venue is only appropriate when the claims "amount to a single cause of action." Archuleta $v$ Sullivan, 725 F Supp 602, 606 (D DC 1989). This is incorrect, as Beattie recognized two distinct approaches to pendent venue, one not requiring the claims to "amount to a single cause of action." Beattie, 756 F2d at 104.

118 Reuber v United States, 750 F2d 1039, 1048 (DC Cir 1984). 
"limitations and conditions upon which the Government consents to be sued must be strictly observed and exceptions thereto are not to be implied." "119 Due to these principles, at least one court has stated that there is "a strong negative presumption against courts finding discretionary pendent venue elsewhere" in a FTCA claim. ${ }^{120}$

\section{Broad Special Venue Claims with Pendent General Venue Claims}

Some statutes have a special venue provision that, rather than replacing the general venue provision, supplements it. Thus, claims arising under the statute can be brought under either the statute's venue provision or the general venue provision. As expected, pendent general venue claims can exist. Here, plaintiffs seeking to bring both claims and take advantage of the broad venue provision (by bringing the claims in a district allowed by the special venue provision but perhaps not allowed by the general venue provision) must advocate the use of pendent venue in order to bring in the general venue claim.

Securities and RICO cases make up a significant portion of the broad special venue claims in which pendent venue is invoked. The reasons are perhaps twofold. First, both securities and RICO claims are subject to special venue provisions that provide a broad range of districts in which a plaintiff can bring a claim. ${ }^{121}$ Second, many state laws cover the same acts as federal securities laws and the RICO Act. ${ }^{122}$ Thus, plaintiffs will often have pendent state claims for these actions.

The approach taken by courts to this situation is fairly uniform. Rather than transferring to a district where venue is proper under both Section 1391 and the specialized venue provision or dismissing the improperly venued claim, the pendent general venue claims are let in. ${ }^{123}$ The justification for this tends to be scant. Some courts state that

119 Lehman v Nakshian, 453 US 156, 161 (1981), quoting Soriano v United States, 352 US 270,276 (1957).

120 Reuber, 750 F2d at 1049.

121 See Securities Exchange Act of $1934 \S 27,15$ USC \& 78aa (1994) (Venue is proper in a district where the defendant is an inhabitant, the defendant is found, the defendant transacts business, or any act or transaction constituting the violation occurred.); 18 USC $\$ 1965$ (a) (Venue under RICO is proper in any district where the party being prosecuted "resides, is found, has an agent, or transacts his affairs.").

122 See, for example, Travis v Anthes Imperial Ltd, 473 F2d 515, 520 (8th Cir 1973) (common law fraud claim brought based on same facts as $\S 10(\mathrm{~b})$ violation and Rule $10 \mathrm{~b}-5$ violation).

123 See, for example, id at 528-29; Miller v Asensio, 101 F Supp 2d 395, 409 (D SC 2000); Hudson Venture Partners, LP v Patriot Aviation Group, Inc, 1999 US Dist LEXIS 1518, *15-16 (S D NY 1999); Abbey v Henzel, 731 F Supp 1431, 1436 (E D Mo 1990); Egan v Duell, 1989 US Dist LEXIS 3919, *10-11 (N D III); Wichita Federal Savings and Loan Association v Landmark Group, Inc, 674 F Supp 321, 329-30 (D Kan 1987); Fireman's Annuity and Benefit Fund of Chicago v Union Planters National Bank, 1987 US Dist LEXIS 4510, *6-7 (N D III); Garfinkle v Arcata National Corp, 360 F Supp 1296, 1298 (S D NY 1973). 
"judicial economy" and "fairness and convenience" justify bringing the state claims in under pendent venue. ${ }^{124}$ Many courts simply cite the existence of pendent venue and use it without further discussion. ${ }^{125}$ At least one case, Egan $v$ Duell, ${ }^{126}$ has argued the case for pendent venue in this circumstance using an amalgamation of the "principal cause of action" approach and the "one cause of action" approach. ${ }^{127}$ In this case, a group of individuals made a variety of statements and presentments inducing plaintiffs to invest in a partnership. ${ }^{128}$ The plaintiffs alleged that the statements were false and misleading and sued in Illinois under the federal securities acts of 1933 and 1934, the RICO Act, and common law fraud and breach of fiduciary duty. ${ }^{129}$ Some of the defendants presented the allegedly false information in Illinois, and thus venue was proper for the securities claim against them. ${ }^{130}$ The court did not even discuss the other claims against those defendants, and instead went right to the application of pendent venue. ${ }^{131}$

'[T]he heart of plaintiffs' case is their count for alleged violations of the federal securities fraud laws," ${ }^{, 132}$ the court stated, mirroring the language in Laffey. ${ }^{133}$ The court then suggested that "[p]laintiffs' complaint essentially states one cause of action for securities fraud, but several claims for relief sounding in RICO and common law fraud and breach of fiduciary duty,"134 a statement that seems to follow the "one cause of action" approach found in Beattie. ${ }^{135}$ The court ended up transferring the entire case to another district, as convenience was better served.

\section{A CRITIQUe OF THE COMMON APPROACHES TO PENDENT VENUE}

How should we evaluate the many approaches to pendent venue taken by the courts? Venue is entirely controlled by Acts of Congress, ${ }^{137}$ and as such, the primary test is whether the approach to pen-

124 See Travis, 473 F2d at 528-29; Egan, 1989 US Dist LEXIS 3919 at *11.

125 See Miller, 101 F Supp 2d at 409; Dooley v United Technologies Corp, 786 F Supp 65, 81

(D DC 1992); Abbey, 731 F Supp at 1436; Lopez v Preferred Savings Bank, 1989 US Dist LEXIS 18066, *6-7 (E D Va).

1261989 US Dist LEXIS 3919 (N D III).

127 Id at *10. See text accompanying notes $132-36$.

128 Id at *4-5.

129 Id at *1.

130 Id at *8-9.

131 Id at $* 10$.

132 Id.

133 See text accompanying notes 71-75.

134 Egan, 1989 US Dist LEXIS 3919 at *10-11.

135 See text accompanying notes 91-112.

136 See Egan, 1989 US Dist LEXIS 3919 at *19.

137 See Wright, Law of Federal Courts $\S 10$ at 239 (cited in note 14). 
dent venue meshes with congressional intent as expressed in the venue statutes. This is precisely the route followed by the United States Supreme Court. ${ }^{1.88}$ If an approach is not warranted by the language of the statute, the Supreme Court has rejected it. ${ }^{139}$ Thus, pendent venue will only be appropriate if it can be reconciled with the language of the statutes. At the same time, the recognized purpose of venue (the convenience of litigants, witnesses, and the court system) can help inform the interpretation of the statutes. ${ }^{140}$ In particular, it would be very wasteful to have two separate trials for what is essentially one case. For this reason, an interpretation that allows for the use of pendent venue in such cases is preferred over one that does not (presuming that both are within the statutory language). Finally, certainty and predictability are both useful in law. Ideally, a particular test would be fairly easy to understand and apply. An approach to pendent venue based on a judge's hunch alone (with no articulated standards) is not as desirable as a clearer test. ${ }^{141}$ With this is mind, we can evaluate the several approaches to pendent venue taken by the courts.

\section{A. The "Procedural Convenience" Approach}

The "procedural convenience" approach is one of the two approaches taken by the Beattie court to justify the use of pendent venue. Here, a purely discretionary approach analogizing to pendent jurisdiction is taken. Basically, whenever a court feels it is appropriate and convenient to hear two pendent claims together and where one is properly venued, the court can hear both claims. The biggest advantage to this approach is flexibility: it allows courts to prevent the waste of repetitive trials by hearing multiple claims together. The procedural convenience approach ${ }^{142}$ also contains a number of weaknesses. It provides neither an accurate description of how pendent venue cases actually come out, ${ }^{143}$ nor a correct statement of the law of pendent juris-

138 Note particularly the strong language found in Olberding $v$ Illinois Central Rail Co, 346 US 338, 340 (1953), and cited again approvingly in Leroy, 443 US at $184 \mathrm{n} 18$ : "The requirement of venue is specific and unambiguous; it is not one of those vague principles which, in the interest of some overriding policy, is to be given a 'liberal' construction."

139 See Lexecon Inc, 523 US at 40; Leroy, 443 US at 184.

140 See Neirbo Co v Bethlehem Shipbuilding Corp, 308 US 165, 167-68 (1939).

141 A discussion of this requirement goes beyond the scope of this Comment. I hope that this proposition, if at least nothing more than a tiebreaker, is unobjectionable.

142 See text accompanying notes $110-20$.

143 This approach seems to suggest that any time judicial economy is served, a court can decide to hear pendent claims as long as any one of the claims is properly venued. See Beattie, 756 F2d at 103 (stating that "[w]hether to apply the principle of pendent venue in any given case is a discretionary decision, based on applicable policy considerations"). However, in many patent infringement/general venue claim cases, the proofs and issues are truly identical, yet many courts still refuse to apply pendent venue when the patent infringement is not properly venued. See text accompanying notes 47-49. Thus, this "procedural convenience" approach does not explain 
diction. ${ }^{14}$ In effect, this approach circumvents congressional mandates without justification. ${ }^{145}$ The Supreme Court has noted that " $[t]$ he requirement of venue is specific and unambiguous; it is not one of those vague principles which, in the interest of some overriding policy, is to be given a 'liberal' construction." ${ }^{146}$ One can easily hypothesize cases in which the general venue provision mandates one of the least convenient districts to hear the case. Thus, a justification based only on "judicial economy" or "convenience" cannot be enough, otherwise the general venue provision itself could be ignored, which is completely at odds with the Supreme Court.

\section{B. The "Principal Cause of Action" Approach}

Under the "principal cause of action" approach, a judge is to discover the "heart of the plaintiffs" case" ${ }^{147}$ and then apply the venue provision of this "principal" claim. ${ }^{148}$ This approach has merit. It allows the use of pendent venue to bring in various claims, thus preventing the risk of repetitive trials or forcing a plaintiff to abandon a claim. This approach also provides a check against the slippery slope of some of the other approaches, namely how to prevent plaintiffs from bringing lesser claims with broader venue provisions to circumvent the congressionally mandated narrow venue provisions in some statutes. By applying the venue provision of the principal claim, a judge can prevent such a tactic.

This justification, however, has several weaknesses. The first is that the theory itself does not tell a judge what the principal cause of action is. Is it the claim for which the plaintiff alleges the most facts? If so, a plaintiff could rework the complaint to allege more detail for the claim he or she wishes to be classified as principal. Is it the claim by

these cases very well.

144 In Gibbs, the Supreme Court did not "avoid the constitutional limitations on the jurisdiction of the federal court" for the sake of "procedural convenience." Beattie, 756 F2d at 101, quoting Wright, Law of Federal Courts $\$ 10$ at 32 (cited in note 14). Gibbs explicitly argued that both the pendent state law claims and the federal claims "comprise[d] but one constitutional "case," and thus the federal court had the power under Article III of the US Constitution to hear "the entire action." 383 US at 725 . The Supreme Court stated explicitly that the Constitution did not bar the federal courts from hearing both claims. Thus, no "constitutional limitations" were "avoid[ed]." Beattie, 756 F2d at 101, quoting Wright, Law of Federal Courts $\$ 10$ at 32.

145 The justification often used is the usual "judicial economy" or "convenience of witnesses" and such. See Beattie, 756 F2d at 102-03. But mere convenience is not enough to simply ignore the venue provisions. See Leroy, 443 US at 183 (rejecting a convenience argument that would circumvent the plain language of the general venue provision). Courts do not allow a claim to be heard (barring some use of pendent venue, of course) in an improper district simply because it would be convenient. See id.

146 Leroy, 443 US at 184 n 18, quoting Olberding v Illinois Central Railroad Co, 346 US 338, 340 (1953).

147 See Egan, 1989 US Dist LEXIS 3919 at *10.

148 See the Hayes/Laffey discussion in text accompanying notes 71-82. 
which the plaintiff would receive the most money? If so, problems arise when it is difficult to tell how much the plaintiff would receive, or when the amounts expected to be received are nearly identical, or when the plaintiff seeks an injunction rather than money damages. It appears that this approach simply lets a judge use his or her "hunch," with no particular guidance.

A refinement of the "principal cause of action" approach can be teased out of Hayes. ${ }^{149}$ The approach can be described as follows: When the plaintiff is bringing multiple claims arising out of the same nucleus of operative facts, one should find the statute that most specifically acts to remedy the wrong arising from these facts. This is the principal cause of action, and venue need only be proper for the principal claim under this approach. ${ }^{1.5}$ This solves some of the uncertainty associated with the "principal cause of action" approach. This refinement has its own problems, however. For instance, suppose the statute that most specifically remedies the wrong has a recovery capped at a small amount. Then the plaintiff is probably more interested and more focused on the broader statutory claim (as the amount he or she can recover is higher) and probably considers it the most important claim. But under the Hayes refinement, the principal claim would be defined as the one arising under the capped claim.

Even the added refinement does not save this approach from its major weakness: a lack of statutory support. The venue provision for Title VII does not say "[the venue provision found at 42 USC $\S 2000 \mathrm{e}-$ 5(f)(3)] shall govern civil actions brought hereunder unless the Title VII claim is not the principle claim;" it says "shall govern." provision is mandatory and does not supplement the general venue provisions. ${ }^{152}$ Allowing a Title VII claim to be heard outside the particular districts violates the clear language of the statute. This is true even if another claim under a broader venue provision arises from the

$149546 \mathrm{~F}$ Supp at 661.

150 The Hayes court addressed this approach in questioning which claim is the principal claim. The Hayes court noted that 42 USC $\S 1981$ is a broader, more general provision than Title VII, a statute specifically fashioned to address employment discrimination, the root of the action brought by the plaintiff. See $546 \mathrm{~F}$ Supp at 664 . After noting this, the Hayes court concluded that "Title VII should be considered a principal cause of action whenever it is joined with a cause of action under 42 USC $\$ 1981$." Id at 665 . Thus, the statute more narrowly focused on the wrong inflicted on the plaintiff is classified as the "principal" cause of action. This meshes with the approach in Laffey, as well. Since the Equal Pay Act is a statute more narrowly covering the particular wrong inflicted on the plaintiff (unequal pay for equal work) than Title VII (a broader statute covering all forms of employment discrimination based on, inter alia, gender), the Equal Pay Act claim would be the "principal" claim. This is exactly what the Laffey court held. See Laffey, 321 F Supp at 1042.

151 See 42 USC $\$ 2000 \mathrm{e}-16$ (d) (emphasis added).

152 See Johnson v Payless Drug Stores, 950 F2d 586, 587-88 (9th Cir 1991), quoting Bolar v Frank, 938 F2d 377, 379 (1991). 
same facts. The fact that another different claim could be brought under the same facts as the Title VII claim does not change the Title VII claim into a non-Title VII claim. This same problem arises in other narrow special venue provisions. ${ }^{1.53}$ This flaw is fatal. A court cannot "in the interest of some overriding policy" ignore a "requirement of venue [that] is specific and unambiguous." Without statutory authorization from Congress, a federal court cannot hear a narrow special venue claim even if it arises from the same common nucleus of operative facts as a general venue claim.

\section{The "One Cause of Action" Approach}

The "one cause of action" approach is stated and followed in Beattie $^{155}$ as one of the two independent grounds to justify pendent venue. Basically, the approach is: where two or more claims are really one cause of action asserting multiple claims for relief, then venue is proper for all claims as long as it is proper for one claim. This approach certainly allows for the use of pendent venue to promote judicial economy and efficiency. It is also a fairly clear rule, although some difficulty can arise in determining precisely what claims are really "one cause of action" with "several grounds for relief." Plus, and perhaps most importantly, this approach is not necessarily inconsistent with the statutory language of the various venue provisions. The approach basically interprets the phrases "action," "claim," or "cause of action" found in the venue provisions consistent with the very broad meaning found in Hurn v Ouersler. ${ }^{156}$ With this broad interpretation, the result meshes with the statutory language: after all, the plaintiff is bringing the cause of action in a proper venue (where the venue provision for one of the claims is satisfied, under the broad cause of action meaning).

The "one cause of action" approach suffers from some difficulties. The first one is a logical problem: the conclusion does not necessarily flow from the premises. The claim, as made in Beattie, is that where the multiple claims are properly characterized as "one cause of action with two [or more] grounds for relief," claim is enough to bring in the other claims. But an equally valid ar-

153 The patent venue provision does use the word "may" as opposed to "shall," which is usually considered permissive rather than mandatory. However, Supreme Court precedent has held that 28 USC 1400(b) is exclusive rather than supplemental. See Fourco Glass Co v Transmirra Products Corp, 353 US 222, 229 (1957).

154 See Leroy, 443 US at 184 n 18, quoting Olberding v Illinois Central Railroad Co, Inc, 346 US 338, 340 (1953).

$155756 \mathrm{~F} 2 \mathrm{~d}$ at 100.

156289 US 238, 246 (1933), quoting Baltimore Steamship Co v Phillips, 274 US 316, 321

157 Beattie, 756 F2d at 100. 
gument can be made that the reverse conclusion is established: where multiple claims are brought, venue must be proper for each claim. ${ }^{1.8}$ Without saying more, this approach does not provide a good justification for the use of the pendent venue doctrine.

The second problem is that this approach is too broad. In particular, this approach does not differentiate between claims properly brought under the general venue provision and those properly brought under a specific venue provision. If a Title VII claim and a Section 1981 claim are really just one cause of action, and venue need only be proper for one of these claims, then it seems that venue need only be proper for the Section 1981 claim, even if the 1981 claim is not the "principal" claim. Yet, this would allow the "principal" Title VII claim to be brought in improper districts as pendent to a 1981 claim, a result rejected by every court and contrary to the mandatory language of 42 USC $\$ 2000 \mathrm{e}-16(\mathrm{~d}){ }^{159}$ This point also forms a basis for a criticism of the statutory interpretation used in the "one cause of action" approach. Under this approach, one need only have one of the claims be satisfied to have venue be proper for the entire claim. According to this approach, narrow special venue provisions are interpreted to be meaningless. As one court noted, a Section 1981 claim will almost always arise out the same facts as a Title VII claim. ${ }^{160}$ Thus, any plaintiff seeking to bring a Title VII claim outside the districts allowed by its venue provision will merely need to allege a Section 1981 claim, and then he or she will be able to bring the entire case in a district allowed by the general venue provision. A similar situation will exist for patent infringement claims and various state claims such as unfair competition. So, the narrow special venue provisions in these cases will never actually serve to limit venue (except for an incautious plaintiff), and thus are rendered superfluous. Given that Congress presumably intended that the special venue provisions would at least sometimes restrict the venue of claims arising under the statutes in question, this interpretation should be disfavored.

158 To elaborate: Assume that we have a patent infringement claim and a common law unfair competition claim. According to the "one cause of action" approach, these two claims are really one cause of action. Since this is one cause of action, it can be said that this cause of action is both a patent infringement action and a common law action. Since this cause of action is a patent infringement action, 28 USC $\S 1400$ (b) states that it must be brought in certain districts. Since this cause of action is also a common law action, 28 USC $\$ 1391$ (b) states that it must be brought in certain other districts. Thus, this cause of action, being both a patent infringement and a common law action, requires that both 28 USC $\S 1400$ (b) and 28 USC $\S 1391$ (b) be satisfied for venue to be proper.

159 See Part I.B.2.

160 Hayes, $546 \mathrm{~F}$ Supp at 665 (" $[\mathrm{P}]$ endent venue could conceivably be invoked in every Title VII case through the mechanism of joining a companion cause of action under 42 U.S.C. § 1981."). 


\section{The "Special Venue" Approach}

The special venue approach ${ }^{161}$ begins with the correct observation that Congress, for certain claims, has specified the districts in which certain claims must be brought. Courts following this approach reject attempts to circumvent this clear congressional mandate. ${ }^{162}$ The most important requirement for an interpretation of venue provisions is satisfied by this approach: the adherence to the text and the congressional intent (as expressed in the statute) of the venue provisions.

However, there are at least two problems with this approach. First, it does not provide an answer in the situation where two or more claims are covered by different special venue provisions. ${ }^{163}$ Second, it would lead to the logical conclusion that general venue claims cannot be brought as pendent to broad special venue claims. This problem is not fatal, of course. Perhaps general venue claims cannot be brought in as pendent to broad special venue claims. However, if possible, an interpretation that avoids this result would be better. ${ }^{164}$ Still, this approach does describe the outcomes in most cases involving narrow special venue claims.

\section{A THEORY OF PENDENT VENUE}

In light of the different approaches taken by courts on the subject, some coherent theory of pendent venue is needed. It is helpful at this point to state what a theory of pendent venue would need to show, given the current status of the law. First, and most importantly, any such theory must comport with the text and congressional intent of the venue statute. This requirement is mandated by the Supreme Court's interpretations of venue provisions, and mandated by the fact that acts of Congress have full authority and control over venue. Second, the theory should, if possible, allow for pendent venue in some cases, to permit the efficient hearing of claims and prevent needless trial repetition. Third, the theory ideally should not be dependent on vague judicial "hunches" for resolution of difficult issues. Before the theory is described, explanations will be given for why we both should not allow narrow special venue claims to be brought as pendent to general venue claims, and why general venue claims should be allowed as pendent to broad general venue provisions.

161 See text accompanying notes $39-49$ and $83-88$.

162 See, for example, United States v Trucking Management, Inc, 1979 US Dist LEXIS 10951, *28-29 (D DC); Johlar Industries, Inc v Essex Engineering Co, 1988 US Dist LEXIS 7623,*8 (N D III).

163 Such as in Egan, 1989 US Dist LEXIS 3919 at *10-11.

164 The more thorough explanation for why such an interpretation is preferred can be found at Part III.B. 
A. Justification for Refusing to Allow a Narrow Special Venue Claim to Be Brought with a General Venue Claim

Some courts occasionally allow a narrow special venue claim to be brought as pendent to a general venue claim. These claims can be brought in either through a discretionary application of the "procedural convenience" approach (as in Beattie), through a determination that the narrow special venue claim is not the "principal" claim (as in Laffey), or through a recognition that the narrow venue claim is part of the same "cause of action" as the general venue claim, and thus the general venue claim need be the only one with proper venue (as in Beattie). With all of these approaches used to justify the use of pendent venue in this context, an explanation as to why pendent venue should not be allowed in this circumstance is useful. Based on the principle that the statutory language and interpretation thereof is the basis for any approach to pendent venue, there are two reasons why allowing pendent venue in the narrow special venue context is improper.

The first is the application of the canon of construction that the special should control over the general. ${ }^{165}$ The Supreme Court has viewed the foundation for this canon "as a warning against applying a general provision when doing so would undermine limitations created by a more specific provision." propriate in the present context. By passing a narrow special venue provision as part of a statute, Congress presumably wanted this provision to apply to claims arising out of this statute. This is presumably true even if another claim could conceivably be brought under the same facts. If presented with a choice as to which venue provision is controlling, the general venue provision or a special, limiting venue provision, the canon clearly supports the use of the limiting venue provision. This is the principle found in Fourco Glass Co v Transmirra Products Corp, ${ }^{167}$ and Fourco is still cited by recent Supreme Court decisions as support for this proposition. ${ }^{168}$ Thus, even if we view all claims arising from a set of facts as being "one cause of action," the special venue provision should control over the general venue provision.

The second reason is based on the principle that one should not use a particular interpretation that renders statutory text, clearly en-

165 See Varity Corp v Howe, 516 US 489, 511 (1996) (noting the presence of this particular canon of statutory interpretation).

166 Id. In fact, the Court in this discussion cites Fourco directly as a way of supporting this proposition!

167353 US 222, 228 (1957) (holding that 28 USC $\$ 1400$ (b) was the exclusive venue provision governing patent infringement claims).

168 See Varity, 516 US at 511. 
acted by Congress with the intent that it would apply in at least some situations, entirely superfluous. Any approach allowing pendent venue to bring in narrow special venue claims attached to general venue claims would render the narrow special venue provisions meaningless. As noted above, a general venue claim will almost always arise from the same set of facts as the narrow special venue claim. Any plaintiff seeking to circumvent the restrictive venue requirements of the narrow special venue claim could do so simply by alleging the general venue claim and using pendent venue. This is an absurd result: by creating a narrow special venue provision for claims arising from a particular statute, Congress presumably wanted the provision actually to limit where the claims were brought! (Why else would it enact the venue provision in the first place?) Thus, any interpretation of the various venue provisions that allows pendent venue to bring in improperly venued narrow special venue claims should be strongly disfavored compared to an interpretation that disallows pendent venue in these cases.

\section{B. Justification for Allowing Pendent General Venue Claims to Be Brought with Broad Special Venue Claims}

As noted above, the justification for using pendent venue in this situation is underdeveloped. ${ }^{169}$ It ignores the very possible solution of transferring all claims to a district where venue is proper for each claim. Some explanation is needed to show why this solution is not adequate.

The explanation, however, is readily apparent. Congress, in enacting the broad venue claims of, say, the RICO Act, clearly intended to broaden the number of districts in which a RICO claim could be brought. ${ }^{170}$ A RICO claim will very often have pendent general venue claims, arising out of the same facts as the RICO claim, such as state law claims for tortious interference with contract or civil conspiracy." Without the use of pendent venue, it is conceivable that in many cases an individual wishing to pursue both state and federal claims will be unable to take advantage of the broadened venue provisions of the RICO Act, contrary to the will of Congress.

To see this, consider an individual contemplating suit in district $A$ for acts which are covered by both the RICO Act and various state laws. Assume that the RICO claim would be properly venued in dis-

169 See text accompanying notes 121-36.

170 See Farmers Bank of Delaware v Bell Mortgage Corp, 452 F Supp 1278, 1280-81 (D Del 1978) (stating that "[g]iven the language and legislative history of Section 1965 [of RICO] ... its provisions were not intended to be exclusive, but rather, were intended to liberalize the already existing venue provisions found in Title 28 ").

171 See, for example, Sadighi v Daghighfekr, 36 F Supp 2d 267, 269-70 \& n 2 (D SC 1999). 
trict $A$, due to the special venue provision of the RICO Act. Assume also that venue for any general venue claim would be proper only in district $B$. The individual wants to bring both the state law claim and the RICO claim. What can the individual do?

If pendent venue were not an accepted doctrine, the individual could not bring both claims in district $A$. If the individual tried to bring both claims simultaneously, the RICO claim in $\operatorname{district} A$ and the state claim in district $B$, the identical proofs and witnesses for both claims would make the two actions ripe for consolidation. ${ }^{12}$ Given that the state law claim could not be transferred to district $A,{ }^{173}$ it is likely that the RICO claim would be transferred to district $B$. If the individual were to assert only the RICO claim in district $A$, and after it was adjudicated, try to bring the state law claim in district $B$, he or she is at risk of being barred by res judicata from raising the state law claim. ${ }^{174}$ Even if neither consolidation nor res judicata were applied, the individual might experience significant financial difficulties and time delays by bringing two separate actions for what is essentially a single wrong.

Thus, without pendent venue, it appears that the individual would often either have to forgo his or her right to bring the RICO claim in district $A$, or forgo his or her right to bring the state law claim altogether. This would act to hinder the congressional intent of allowing a broad choice of districts for RICO plaintiffs. ${ }^{175}$ Thus, the language of the various venue provisions should be interpreted so as not to thwart the purposes of the broad special venue provision of the RICO Act (or, indeed, any statute governed by a broad special venue provision). ${ }^{176}$

172 See FRCP 42(a); 28 USC \$ 1404(a) (1994); Coady v Ashcraft \& Gerel, 223 F3d 1, 11 (1st Cir 2000) (noting that the possibility of consolidation is one of the factors to weigh in determining whether to transfer a case).

173 See 28 USC § 1404(a) (stating that "a district court may transfer any civil action to any other district or division where it might have been brought") (emphasis added); Hoffman $v$ Blaski, 363 US 335, 343-44 (1960) (ruling that a court can transfer a case only to districts where venue would have been proper had the case originally been brought there).

174 See Restatement (Second) of Judgments § 24(1) (1982) (stating that res judicata is applied to claims arising from the same transaction or series of transactions as the decided claim).

175 See note 170.

176 This approach to statutory interpretation is quite common. For example, the Supreme Court noted its appropriateness in United States v John Doe, Inc, I, 481 US 102, 109 (1987) (noting that "policy arguments" are "relevant when language is susceptible of more than one plausible interpretation"). See also United States v Fejes,232 F3d 696, 701 (9th Cir 2000) (noting that an interpretation that is consistent with the language of the statute and avoids absurd results is preferable when nothing in the language or legislative history suggests that Congress intended such an absurd result). The other approaches that justify pendent venue with policy arguments either are inconsistent with or completely ignore the statutory language, and thus these cases cannot help them. 


\section{The Theory of Pendent Venue}

The basic approach for this Comment's theory of pendent venue is to use the broad concept of "cause of action" endorsed by some Supreme Court cases." When a plaintiff brings multiple claims, one should look to all claims that arise out of the same common nucleus of operative facts. ${ }^{178}$ All these claims should be considered "one cause of action" for venue purposes. ${ }^{179}$ Then, if any of these claims were governed by a narrow special venue provision, that claim should only be brought in districts specified in that venue provision. The reasoning is the same as mentioned in most of the Title VII cases and almost all of the patent infringement cases: congressional intent to limit the available districts is clear, and cannot be circumvented by claims of pendent venue. ${ }^{180}$ Congress limited where these causes of action could be brought, whether the cause of action is viewed narrowly or broadly. As noted above, even if a court considered all the claims arising out of the same nucleus of operative facts as "one cause of action," this still does not allow the court to bring this "cause of action" outside the districts provided for by Congress.

In particular, the court in Hsin $\operatorname{Ten}^{182}$ is incorrect. Fourco has yet to be overturned; thus, patent infringement cases are still exclusively covered by 28 USC $\S 1400($ b). While 28 USC $\S 1391$ (c) may have modified the patent infringement venue provision to some extent, the general venue provisions of 28 USC $\$ 1391$ (a)-(b) still do not apply to such cases. To allow a patent infringement claim to be brought in as pendent to a general venue claim would still be to circumvent congressional intent and binding precedent as to the proper venue of patent infringement claims. The fact that the set of appropriate districts is now much broader with the amended 28 USC $\S 1391$ (c) does not change the fact that the patent infringement venue provision is a special venue provision. The Federal Circuit in VE Holdings Corp v John-

177 See Gibbs, 383 US at 725; Hurn, 289 US at 245-47. See also Beattie, 756 F2d at 100-04.

178 This approach to defining a cause of action or claim is clearly supported by many commentators. See, for example, Black's Law Dictionary 214, 240 (West 7th ed 1999) (defining "cause of action" as "[a] group of operative facts giving rise to one or more bases for suing" and "claim" as "[t]he aggregate of operative facts giving rise to a right enforceable by a court"); Restatement (Second) of Judgments $\$ 24 \mathrm{cmt}$ a ("The present trend is to see claim in factual terms and to make it coterminous with the transaction."). This approach is also seen in the Federal Rules of Civil Procedure. See, for example, FRCP 13(a) (defining compulsory counterclaims as ones arising from the same transaction or series of transactions).

179 This theory of pendent venue does not depend on the actual definition of the "cause of action." It is perfectly acceptable for some jurisdictions to grant a more restrictive meaning to "cause of action" or "claim." However, having defined the proper scope of a "cause of action," one should apply the rules laid out in this Part.

180 See notes 49 and 87.

181 See Part III.A.

1822000 US Dist LEXIS 18717 at *1. See text accompanying notes $56-64$. 
son Gas Appliance Corp, ${ }^{183}$ in defending the application of 1391(c) to 1400 (b) against the charge that this would act to make 1400 (b) superfluous, noted that $1400(\mathrm{~b})$ is still the exclusive venue provision for patent infringement suits against individuals. ${ }^{184}$ Thus $V E$ Holding itself recognizes the continued exclusive application of 1400 (b).

The key step in justifying the use of pendent venue is to note that the general venue provision applies only if venue is not "otherwise provided by law." vision for one of the claims making up the "one cause of action" brought by the plaintiff, then venue for this cause of action has been "otherwise provided by law," and the general venue provision does not apply. Thus, the pendent general venue claims (perhaps more accurately referred to as claims without special venue provisions) can be brought as part of the more broadly defined and properly venued "cause of action." Although this meaning of the phrase "otherwise provided for by law" is perhaps a strained one ${ }^{186}$ it is certainly plausible. Furthermore, this interpretation avoids the problematic results whereby a plaintiff will possibly be forced to give up his or her ability to sue in a district allowed by a broad special venue provision or give up his or her pendent general venue claim. ${ }^{187}$ This is certainly preferable to any interpretation that hinders congressional intent in broad special venue provisions. Plus, where a special venue provision grants venue for the cause of action, this provision should control over the general provision, allowing the plaintiff to bring the general venue claim under the doctrine of pendent venue. ${ }^{188}$

With this understanding in mind, the use of pendent venue is quite clear: the specialized venue provision, whether broad or narrow, controls the venue for all claims arising under the same common nucleus of operative facts. When a plaintiff brings a broad special venue claim with a general venue claim, we first must see if they arise out of the same nucleus of operative facts. If so, these claims are classified as "one cause of action" for purposes of venue. Then, if the district in

183917 F2d 1574 (Fed Cir 1990).

184 See id at $1580 \mathrm{n} 17$.

185 See 28 USC $\S 1391$ (b).

186 The main purpose of this language in the general venue provisions is likely instead to ensure that the general venue provision does not override other, specialized venue provisions. See Wichita Federal Savings and Loan Association v Landmark Group, Inc, 674 F Supp 321, 32728 (D Kan 1987) (relying on "otherwise provided by law" to find application of 28 USC $\S 1391$ (b) "unnecessary" in light of the Securities Exchange Act's and RICO's special venue provisions). My particular interpretation, however, is quite similar to this in that it emphasizes the default nature of the general venue provision. In fact, it is the natural reading of the language, once a broad notion of "cause of action" or "civil action" is accepted. See Varity Corp v Howe, 516 US 489, 511 (1996).

187 See Part III.B.

188 See Part III.B. 
which these claims are brought is allowed under the special venue provision of the one claim, the other claim can be brought as pendent.

The final step is to determine what to do when there are two claims, brought under different federal statutes, both of which are governed by broad special venue provisions, where only one is properly venued. ${ }^{189}$ The key point to note here is that the main purpose of providing the broad special venue provision is to widen the number of districts in which the claim can be brought, not to limit it. ${ }^{190}$ If a district would be a proper venue for the claim if it were not governed by the special venue provision, then it should not be converted into an improper venue due to the presence of the broad special venue provision. ${ }^{191}$ Plus, the same policy reason exists for this interpretation as to the justification for pendent venue in general. Without the use of pendent venue, a plaintiff might either have to forgo bringing a broad special venue claim in an authorized district, or forgo bringing his or her other broad special venue claim at all. ${ }^{192}$

To consider an example, assume that a plaintiff brings both a Securities Exchange Act claim and a pendent RICO claim, where the Securities Exchange Act claim is properly venued and the RICO claim is not. If the RICO Act did not have a specialized venue provision, it would be governed only by the general venue provision. Under the approach discussed above, the RICO claim could be brought as pendent to the Securities Act claim. ${ }^{193}$ If the specialized venue provision in the RICO Act did not exist, it could be brought in the same district as the Securities Exchange Act claim. Thus, even with the special venue provision, the RICO claim should be allowed as pendent in the same district as the Securities Exchange Act claim. ${ }^{19}$

189 An example, perhaps, of this is Egan, 1989 US Dist LEXIS 3919 at *10-11 (bringing RICO claim brought as pendent to federal securities claim). The court does not analyze whether venue is appropriate for the RICO claim, and thus it is possible that the RICO claim is properly venued. But the lack of analysis is justified on the ground that pendent venue is appropriate. See id.

190 See Farmers Bank of Delaware v Bell Mortgage Corp, 452 F Supp 1278, 1280-81 (D Del 1978). This case notes that the language of the RICO venue provision states that an action "may be brought" in particular districts. See id at 1280 . The court interprets this to mean that the RICO venue provision is permissive, not limiting or exclusive. See id.

191 This follows from the fact that the RICO venue provision is phrased in permissive language, and thus should not prevent a claim from being brought anywhere it could have been brought but for this provision. See note 170. Also note that the Securities Exchange Act venue provision is also phrased in permissive language, see 15 USC $\$ 78 \mathrm{aa}$, and also that it has been held to supplement the general venue provisions. See Miller v Asensio, 101 F Supp 2d 395, 404-08 (D SC 2000). Thus, the same reasoning found in the text of this Comment should apply to Securities Exchange Act cases as well.

192 See Part III.B.

193 See notes $185-88$ and accompanying text.

194 Again, this reasoning is not limited to RICO and Securities Exchange Act claims. Any situation involving two pendent broad special venue claims would follow the same approach 
With two narrow special venue claims, both venue provisions must be satisfied. Despite inconvenience or inefficiency, congressional commands must be followed. Inefficiency cannot be used to justify circumventing the clear mandates of the venue provisions, as the Supreme Court made abundantly clear in Leroy.

\section{Some Applications of the Theory}

First, it should be noted that this theory is not inconsistent with the statutory language. It does not justify pendent venue purely through claims of efficiency or convenience. It relies on a broad notion of "cause of action" used by the Supreme Court itself in several related situations. Second, the theory allows for the use of pendent venue in many circumstances. Thus, inefficiency and inconvenience can still be avoided in the cases where it is most important to do so (such as cases with pendent state law claims attached to broad special venue claims). Third, the theory itself is generally not hard to apply. The judge must merely determine whether a special venue provision is broad or narrow, and then the application of pendent venue flows naturally from that decision. Thus, the most important factors a theory of pendent venue should satisfy are satisfied.

Patent infringement claims are governed by a narrow special venue provision. Thus, according to the theory, pendent venue should not be used to bring a patent infringement claim in with a state claim or trademark claim. All courts (except the Hsin court) have agreed with this outcome, it should be noted. ${ }^{195}$

Title VII is governed by a narrow special venue provision. Thus, under the theory, Title VII cases should be treated the same as patent infringement cases. By and large, most cases do come out this way. A few notable cases might be decided differently in accordance with this theory. ${ }^{196}$ Other courts in cases involving narrow special venue provisions often ignore the mandatory nature of these special venue provisions, and do not consider the important concern of following the will of Congress, especially considering the strong statements of the Supreme Court. ${ }^{197}$ In particular, the "principal cause of action" approach,

mentioned here.

195 See note 47.

196 Laffey is perhaps one. The Laffey court fails to analyze whether venue is appropriate under Title VII's venue provisions; it merely halts the analysis after declaring that pendent venue can be applied. $321 \mathrm{~F}$ Supp at 1042. Perhaps, then, venue is appropriate for the Title VII claim, and Laffey does have the right result, just for the wrong reason.

197 Serpico v Laborers' International Union of North America, 1995 US Dist LEXIS 11237 (N D IIl), is interesting in that a justification for overriding a narrow special venue provision is provided. See note 18 . The court's reasoning is not convincing, however. As noted above, the general venue provision is different from the special venue provisions in that it provides that it should only apply when no other venue provision is appropriate. See text accompanying 
taken by many courts, cannot be used to circumvent the venue requirements of Title VII and other narrow special venue provisions.

FTCA claims, covered by a narrow special venue provision, should be brought only in the particular district allowed by the statute. This principle is especially strong in the FTCA context, as waivers of sovereign immunity are construed narrowly. As noted in cases such as Reuber $v$ United States ${ }^{198}$ and Boggs $v$ United States, ${ }^{199}$ this approach is generally followed. The classic pendent venue case, Beattie, is exceptional in that the court there was trying to avoid a "venue gap," and thus the case was perhaps correctly decided. But, for all other FTCA cases in which no venue gap exists, pendent venue should not be used.

All the cases involving a broad special venue claim with pendent general venue claims are also explained by this theory. The use of pendent venue in these circumstances is one of the important features that a theory of pendent venue should explain, and thus the theory gives the correct result in these cases and provides a strong justification for this result. It also justifies the use of pendent venue in the circumstance where two broad special venue claims are brought and venue may be proper only for one.

\section{CONCLUSION}

Pendent venue is a doctrine that currently lacks a theory. Through the mix of lawsuits and circumstances, some certainties arise. In some cases the use of such a doctrine was rejected, but in others it was widely accepted. No court has been quite able to explain the varying results. If not properly contained, the pendent venue doctrine could extend beyond all bounds, allowing courts to ignore basic congressional mandates without any good justification beyond "judicial economy." But, when properly understood, pendent venue is a clearly acceptable and useful doctrine, needed to prevent procedural absurdities, and consistent with the language and intent of the venue provisions. This Comment's theory of pendent venue sheds light on the ideas behind the doctrine, and can be used as a solid foundation for continued application of this interesting and helpful idea. 